\title{
Pressure of Climatic Factors on Sheep Bluetongue Epidemics in Tamil Nadu
}

\author{
S Krishna kumar ${ }^{1 *}$, P Selvaraj ${ }^{1}$, M Veeraselvam ${ }^{1}$, M Ranjith kumar ${ }^{2}$, S Yogeshpriya ${ }^{1}$ and Y Krishna Mohan Reddy \\ ${ }^{1}$ Department of Veterinary Medicine, Veterinary College and Research Institute, India \\ ${ }^{2}$ Department of Veterinary clinical medicine, Madras Veterinary College, India
}

${ }^{3}$ Vaccine research centre -viral vaccines, Director of Animal Health studies, India

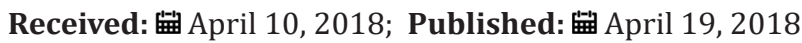

*Corresponding author: S Krishna Kumar, Assistant Professor, Department of Veterinary Medicine, Veterinary College and Research Institute, Orathanadu, India

\begin{abstract}
This research correlates the effect of climatic factors on bluetongue epidemiology in sheep of delta districts in Tamilnadu based on merteriological data collected from 2014 to 2016. There were a total of eighty two villages of delta districts were affected with Blue tongue virus (BTV). We used multiple linear regression analysis to assess the effect of climatic factors on the prevalence of bluetongue. Our results showed that maximum temperature, rain fall and relative humidity positively correlates with the number of BTV epidemic in sheep flocks. These findings suggest that the risk of BTV infections in sheep increased in warm and humid environments. Moreover, climatic factors can be used to forecast the possible epidemic in this area and other regions characterized by similar climatic conditions.
\end{abstract}

Keywords: Epidemiology; Blue Tongue Virus; Culicoides Spp; Laminitis; Coronitis; Facial Edema; Necrosis of Cardiac; Vectorial Capacity; Multiple Linear Regression Analysis Model; Semi Intensive Livestock; Antioxidant System

\section{Introduction}

Bluetongue, is caused by the bluetongue virus (BTV) and transmitted by Culicoides spp. [1,2]. Bluetongue virus was pandemic in nature with areas between $40^{\circ} \mathrm{N}$ and $35^{\circ} \mathrm{S}$ in the world [3,4] . Symptoms of this disease are usually characterized by laminitis, coronitis and facial edema. In serious cases, pulmonary edema, pleural effusion and necrosis of cardiac and skeletal muscle can be observed [5].

Because of the likely impact of climatic conditions on the abundance activity and vectorial capacity of Culicoides spp. for the transmission of bluetongue in affected regions, it has been hypothesized that these climatic factors may influence the epidemic of bluetongue [6-8].

Many researchers have evaluated the correlation between meteorological factors and the distribution of the Blue tongue virus $[9,10]$. However, few researchers have specifically attempted to investigate the influence of climatic factors on bluetongue epidemic. In the present study, we have investigated the effect of climatic factors on the epidemics of bluetongue, by means of multiple linear regression analysis model.We designed to assess the influence of climatic factors on the epidemiology of bluetongue in sheep in Tamilnadu, in order to provide accurate information to design the more effective and economical surveillance and control systems for bluetongue.

\section{Materials and Methods}

\section{Sheep farming of Delta Districts}

In delta districts of Tamilnadu, two types of sheep farms were observed. One is semi intensive livestock farms, which must meet a moderate standard regarding production management and epidemic prevention systems. The other one is high number holdings with trans humane methods, where sheep kept as a freerange system.

\section{Location}

This research work was carried out in the delta region of Tamilnadu which includes Thanjavur, Thiruvarur, Nagapattinam and Pudukottai districts during 2014 to 2016. 


\section{Data collection}

Metrological data were collected from government agencies like District Collector Office and disaster management centre. Data were also obtained from research institutes like Tamilnadu Agricultural University, Thanjavur.

\section{Data analysis}

Multiple linear regression analysis model was used to assess the effect of climatic factors on the epidemics of bluetongue.

\section{Results}

Sums of 608 bluetongue epidemics have been reported in delta districts during the period of study. Then we have analysed the change trend of bluetongue epidemic and the annual variation of meteorological data (Figure1). The results indicated the change trend and the annual variation of the disease epidemics, monthly maximum temperatures, monthly minimum temperature, wind speed and rainfall in delta districts of Tamilnadu from 2014 to 2016. Analyses of time series revealed that the epidemic of bluetongue of a determined month was changed by case numbers registered during the previous years. The epidemic trend was changing with the months were also recorded (Figure 2).

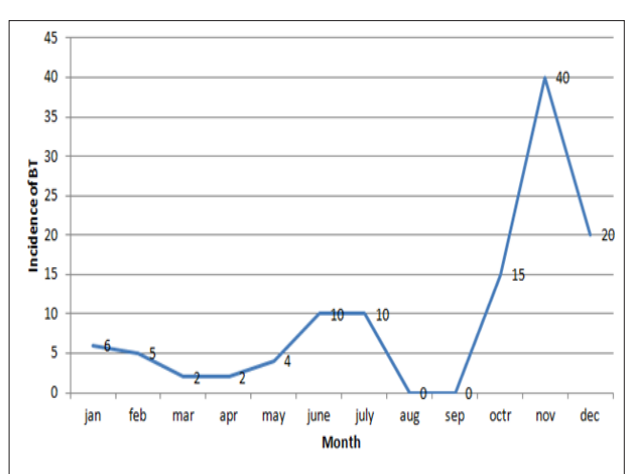

Figure 1: Standard epidemic of Sheep bluetongue in Tamilnadu.

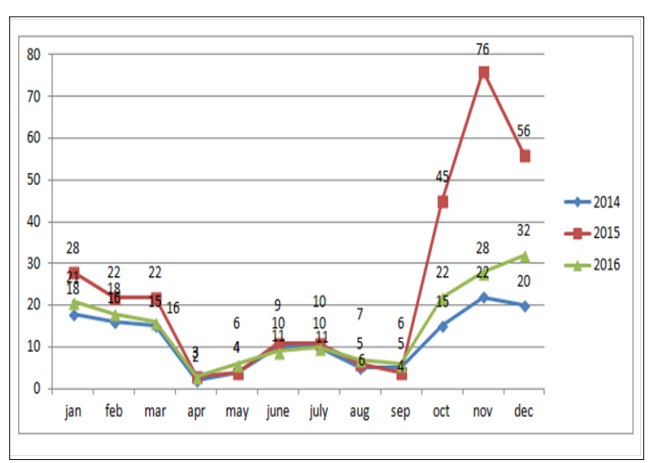

Figure 2: Changing epidemic of Sheep blue tongue in Tamilnadu.

From the year analysis, a seasonal distribution and change in the disease cases from 2014 to 2016 were noticed, which correlates with the climatic factors of our investigation results from the results of data analysis, we found that temperature is the main risk factors which can influence the epidemic of bluetongue (Figure 3). In delta region maximum temperature at the tune of $33^{\circ} \mathrm{C}$ will have higher epidemics during 2015 (288) than in 2013 (142) and in 2016 (178). Rainfall was also showed a influence on the occurrence of disease, a rise in mean monthly rainfall is related to increase in the monthly number of disease cases (Figure 4). High relative humidity positively related to the epidemic of bluetongue (Figure 5). Clinical signs like cutaneous ulcers (Figure 6) and bilateral purulent discharge is evident. Under multiple linear regression model analysis maximum temperature, relative humidity and rainfall were statistically significant $(\mathrm{P}<0.05)$ with the epidemiology of bluetongue (Table 1).

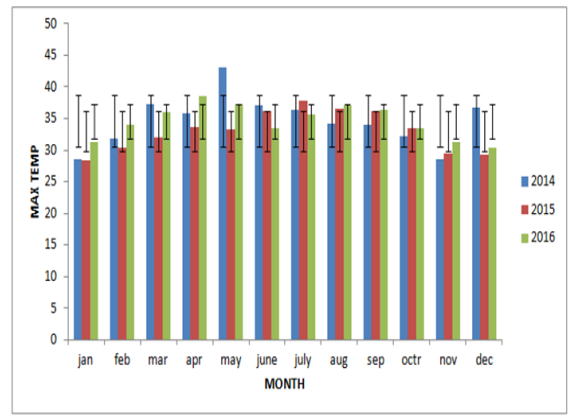

Figure 3: Maximum temperature $\left({ }^{\circ} \mathrm{C}\right)$ data in the study area during 2014 to 2016.

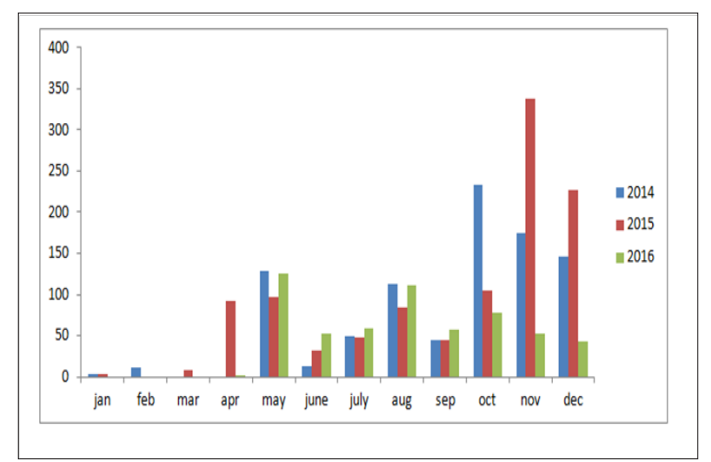

Figure 4: Trend line of Rain fall (mm) in the study area.

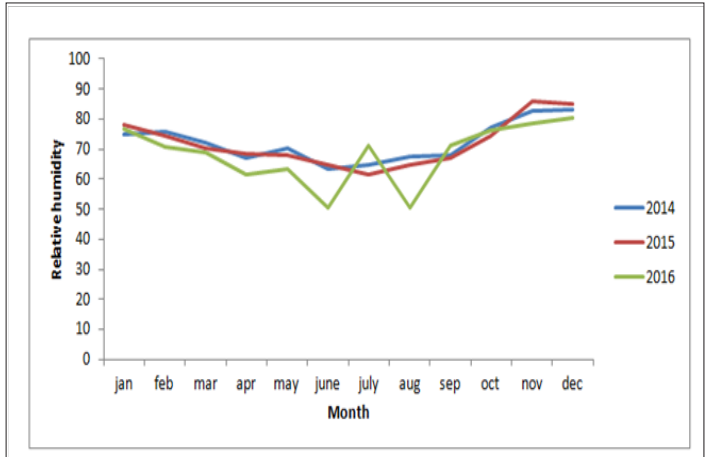

Figure 5: Relative humidity (\%) trend in the study population. 
Table 1: Multiple linear regression model on climatic factor with bluetongue epidemic $(\mathrm{P}<0.05)$.

\begin{tabular}{|c|c|c|c|c|c|c|c|}
\hline \multicolumn{8}{|c|}{ Coefficients ${ }^{\mathrm{a}}$} \\
\hline & \multirow{2}{*}{ Model } & \multicolumn{2}{|c|}{ Unstandardized Coefficients } & \multirow{2}{*}{$\begin{array}{c}\text { Standardized Coefficients } \\
\text { Beta }\end{array}$} & \multirow{2}{*}{$\mathbf{t}$} & \multirow{2}{*}{ Sig. } & \\
\hline & & B & Std. Error & & & & \\
\hline \multirow{6}{*}{1} & (Constant) & -4.242 & 43.077 & & -.098 & .922 & \\
\hline & TEMP_MIN & 1.090 & .800 & .209 & 1.362 & .183 & NS \\
\hline & TEMP_MAX & -1.998 & .710 & -.426 & -2.816 & .009 & ** \\
\hline & RH & .800 & .316 & .421 & 2.531 & .017 & $*$ \\
\hline & Wind speed & -.278 & 1.259 & -.028 & -.221 & .827 & NS \\
\hline & Rain fall & .065 & .024 & .322 & 2.734 & .010 & $*$ \\
\hline \multicolumn{8}{|c|}{ a. Dependent Variable: Bluetongue epidemic } \\
\hline
\end{tabular}

\section{Discussion}

In this study, we aimed to prove the relationship between climatic factors and the epidemiology of bluetongue in delta districts of Tamilnadu. We found that a positive relationship between rainfall, monthly maximum temperature and relative humidity in the epidemic of Blue tongue in Sheep.

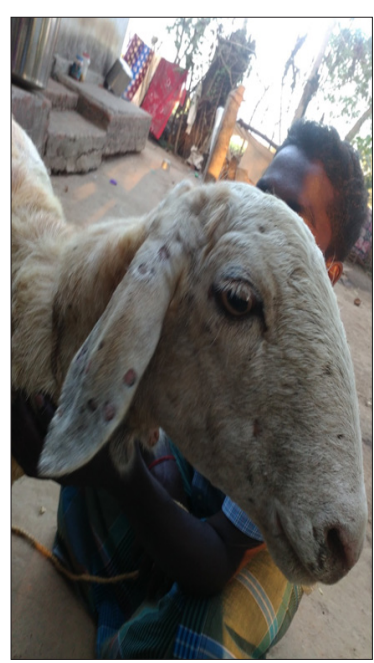

Figure 6: Cutaneous ulcers in Blue tongue.

The positive effect of temperature and relative humidity on blue tongue infections is comparable to previous research [11-13]. It has been proven that a hot and humid environment can interfere with the antioxidant system of the animal and increases the synthesis of lipid peroxides, which may cause peroxide damage [14-16] and increases the serum levels of epinephrine and norepinephrine will negatively affect humoral and cell-mediated immune responses and make animals more susceptible to infectious diseases like bluetongue.

Maximum temperature in our study helps in the epidemic of bluetongue because temperature also significantly influences the activity rates of adult insects. The scientific reason behind is adult culicoides are more active than on cooler days and their reproduction will be inhibited by low temperature [17]. However, BTV has a strong environmental resistance and will not lose its infectivity in seven days under $56^{\circ} \mathrm{C}[18]$. Thus, the effect of temperature may be limited in the normal / lower temperature conditions (Figure 7). High Rainfall showed increased cases of bluetongue because of contamination of soil water and that can influence the life cycle of insects. Moreover at the right level, rainfall can create humid microhabitats which promote activities (19) and can regulatethe growth and activity of Culicoides spp. populations $[20,21]$.Even though this research found that wind velocity did not favors the spread of Bluetongue virus but, long distance movement of Culicoides is mediated by the prevailing winds [21].

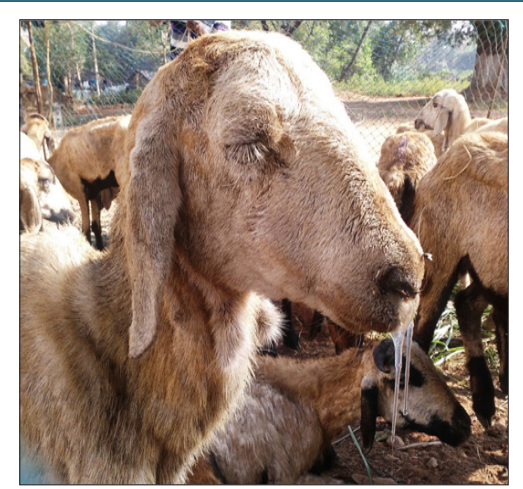

Figure 7: Bi lateral purulent nasal discharge in Blue tongue of Sheep.

As a final point, mechanisms of transmission of bluetongue are more complex and climate factors only represent some components of the epidemic of blue tongue. Many other risk factors like age, immunization calendar and management practices may also have strong impact on the incidence of the disease. In this paper, we only studied the effect of climatic factors on the epidemiology of bluetongue. This research work can able to help to design in the control of blue tongue in sheep by adopting timely vaccination methods, insects management program and healthy ecosystem to make the flock more positive energy and protein balance which will augment the immunity of the herd sustainably.

\section{Acknowledgement}

The authors sincerely thanks the sheep farmers, Director of Animal health studies, TANUVAS, Chennai and The Dean, Veterinary college and research institute, Orathanadu, Tamilnadu for their support. 


\section{References}

1. Verwoerd D, Erasmus B (2004) Bluetongue. In: Infectious Diseases of Livestock 2, pp.1201-1220.

2. Maclachlan NJ, Drew C, Darpel K, Worwa G (2009) The pathology and pathogenesis of bluetongue. J Comp Pathol 141(1): 1-16.

3. Mellor P, Boorman J, Baylis M (2000) Culicoides biting midges: their role asarbovirus vectors. Annu Rev Entomol 45: 307-340.

4. Mellor P, Wittmann E (2002) Bluetongue virus in the Mediterranean Basin1998-2001. Vet J 164(1): 20-37.

5. Patz JA, Olson SH, Uejio CK, Gibbs HK (2008) Disease emergence from global climate and land use change. Med Clin North Am 92(6): 14731491.

6. Maclachlan NJ, Guthrie AJ (2010) Re-emergence of bluetongue, African horse sickness, and other orbivirus diseases. Vet Res 41(6): 35.

7. Wohlsein P, Singh R (2015) Peste des Petits Ruminants in unusual hosts: epidemiology, disease, and impact on eradication. In: Peste des Petits Ruminants Virus Springer 95-118.

8. Purse BV, Mellor PS, Rogers DJ, Samuel AR, Mertens PP, et al. (2005) Climate change and the recent emergence of bluetongue in Europe. Nat Rev Microbiol 3(2): 171-181.

9. Guis H, Caminade C, Calvete C, Morse AP, Tran A, et al. (2012) Modelling the effects of past and future climate on the risk of bluetongue emergence in Europe. J R Soc Interface 9(67): 339-350.

10. Charron DF, Thomas MK, Waltner-Toews D, Aramini JJ, Edge T, et al. (2004) Vulnerability of waterborne diseases to climate change in Canada: a review. J Toxicol Environ Health A 67(20-22): 1667-1677.

11. Kovats RS, Edwards SJ, Hajat S, Armstrong BG, Ebi KL, et al. (2004) The effect of temperature on food poisoning: a time-series analysis of salmonellosis in ten European countries. Epidemiol Infect 132(3): 443453.
12. Tam CC, Rodrigues LC, O'Brien SJ, Hajat S (2006) Temperature dependence of reported Campylobacter infection in England, 19891999. Epidemiol Infect 134(1): 119-125.

13. Morrow-Tesch JL, McGlone JJ, Salak-Johnson JL (1994) Heat and social stress effects on pig immune measures. J Anim Sci 72(10): 2599-2609.

14. Hicks TA, McGlone JJ, Whisnant CS, Kattesh HG, Norman RL (1998) Behavioral, endocrine, immune, and performance measures for pigs exposed to acute stress. J Anim Sci 76(2): 474-483.

15. Hyun Y, Ellis M, Riskowski G, Johnson R (1998) Growth performance of pigs subjected to multiple concurrent environmental stressors. J Anim Sci 76(3): 721-727.

16. Sellers R, Mellor P (1993) Temperature and the persistence of viruses in Culicoides spp. during adverse conditions. Rev Sci Tech 12(3): 733-55.

17. Arjunan N, Kadarkari M, Pari M, Thiyagarajan N, Kumar S (2014) Impact of climate change on filarial vector, Culex quinquefasciatus and control using bacterial pesticide, spinosad. Asian Pacific Journal of Tropical Disease 4(1): S87-S91.

18. Murray M (1991) The seasonal abundance of female biting-midges, Culicoides-brevitarsis Kieffer (Diptera, Ceratopogonidae), in coastal south-eastern Australia. Australian journal of zoology 39: 333-342.

19. Bomblies A, Duchemin JB, Eltahir EA (2009) Hydrology of malaria: model development and application to a Sahelian village. Water Resources Research 54(2): 44

20. Montosi E, Manzoni S, Porporato A, Montanari A (2012) An ecohydrological model of malaria outbreaks. Hydrol Earth Syst Sci 16: 2759-2769.

21. Peters J, Waegeman W, Van doninck J, Ducheyne E, Calvete C, et al. (2014) Predicting spatio-temporal Culicoides imicola distributions in Spain based on environmental habitat characteristics and species dispersal. Ecological Informatics 22: 69-80.
This work is licensed under Creative Commons Attribution 4.0 License

Submission Link:

Submit Article

DOI: $10.32474 /$ CDVS.2018.01.000106

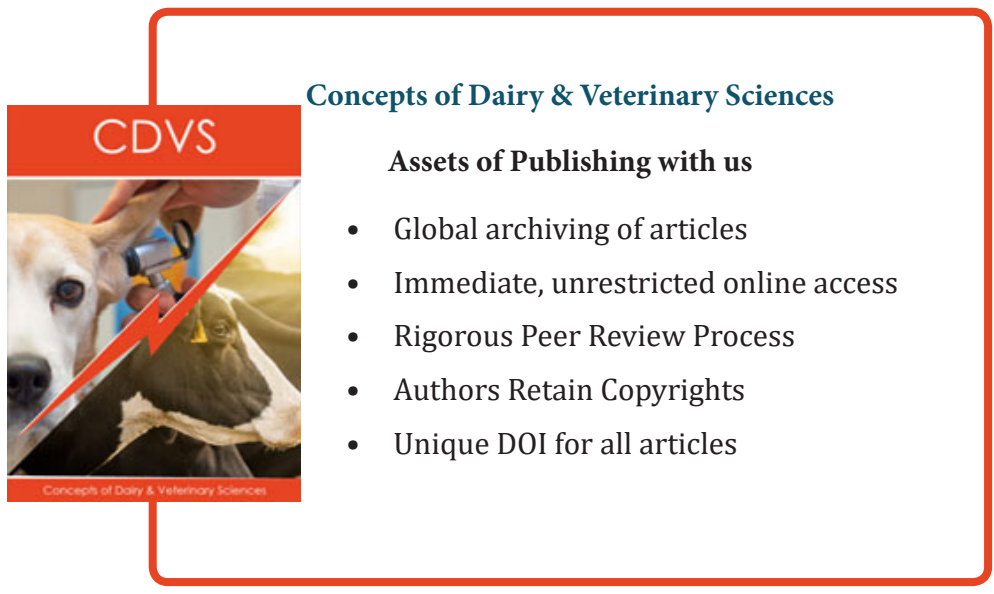

